\title{
Sulfur Release from Cement Raw Materials during Solid Fuel Combustion
}

\author{
Nielsen, Anders Rooma; Larsen, Morten B.; Glarborg, Peter; Dam-Johansen, Kim
}

Published in:

Energy \& Fuels

Link to article, DOI:

10.1021/ef200963v

Publication date:

2011

Document Version

Publisher's PDF, also known as Version of record

Link back to DTU Orbit

Citation (APA):

Nielsen, A. R., Larsen, M. B., Glarborg, P., \& Dam-Johansen, K. (2011). Sulfur Release from Cement Raw Materials during Solid Fuel Combustion. Energy \& Fuels, 25(9), 3917-3924. https://doi.org/10.1021/ef200963v

\section{General rights}

Copyright and moral rights for the publications made accessible in the public portal are retained by the authors and/or other copyright owners and it is a condition of accessing publications that users recognise and abide by the legal requirements associated with these rights.

- Users may download and print one copy of any publication from the public portal for the purpose of private study or research.

- You may not further distribute the material or use it for any profit-making activity or commercial gain

- You may freely distribute the URL identifying the publication in the public portal 


\title{
Sulfur Release from Cement Raw Materials during Solid Fuel Combustion
}

\author{
Anders R. Nielsen, ${ }^{+, \neq * *}$ Morten B. Larsen, ${ }^{\dagger}$ Peter Glarborg, ${ }^{\dagger}$ and Kim Dam-Johansen ${ }^{\ddagger}$ \\ ${ }^{\dagger}$ FLSmidth A/S, Vigerslev Allé 77, DK-2500 Valby, Denmark \\ ${ }^{\ddagger}$ Department of Chemical and Biochemical Engineering, CHEC Research Centre, Technical University of Denmark (DTU), \\ DK-2800 Lyngby, Denmark
}

ABSTRACT: During combustion of solid fuels in the material inlet end of cement rotary kilns, local reducing conditions can occur and cause decomposition of sulfates from cement raw materials. Decomposition of sulfates is problematic because it increases the gas-phase $\mathrm{SO}_{2}$ concentration, which may cause deposit formation in the kiln system. $\mathrm{SO}_{2}$ release from cement raw materials during combustion of solid fuels has been studied experimentally in a high temperature rotary drum. The fuels were tire rubber, pine wood, petcoke, sewage sludge, and polypropylene. The $\mathrm{SO}_{2}$ release from the raw materials was observed to increase when (a) the inlet oxygen concentration decreased, (b) the temperature increased, and (c) when the total surface area of the fuel particles increased. The type of fuel also had a significant effect on the $\mathrm{SO}_{2}$ release. The sequence of $\mathrm{SO}_{2}$ release for fuel particles in the size interval 1-2 $\mathrm{mm}$ was found to be tire rubber granulate $>$ sewage sludge $>$ pine wood sawdust $>$ petcoke $>$ polypropylene flakes. The $\mathrm{SO}_{2}$ release was generally observed to increase when formation of local reducing conditions near the raw material bed increased, as indicated by elevated levels of $\mathrm{CO}$ during the fuel devolatilization.

\section{INTRODUCTION}

Fuel consumption accounts for a significant fraction of the total cement clinker production costs. ${ }^{1}$ Traditionally, cement production has mainly depended on the fossil fuels coal, oil, and natural gas. Due to competition in the cement market, rising fossil fuel prices, and environmental concerns, cement producers have increased the utilization of alternative fuels as a substitute for fossil fuels in order to achieve the most economic fuel mix. In this context, "alternative fuels" cover all nonfossil fuels and waste from other industries. Popular alternative fuels in the cement industry are tire-derived fuels, biomass residues, and different commercial and industrial wastes.

It is attractive to utilize coarse, solid alternative fuel particles in the material inlet end of cement rotary kilns in order to save the expense of shredding of the fuels to smaller particles and to increase fuel flexibility of the system. High temperatures in the rotary kiln and material retention times of several minutes provide good conditions for fuel burnout. Figure 1 show how coarse, solid alternative fuels can be introduced into the material inlet end of a cement rotary kiln.

Sulfur is introduced to cement rotary kilns as inorganic bound sulfur in the preheated and calcined cement raw materials or with the fuels (see Figure 1). A detailed description of sulfur species and the main sulfur reactions in rotary kilns and calciners is described elsewhere., ${ }^{2,3}$

Sulfur present in the calcined raw material is mainly bound as $\mathrm{CaSO}_{4}$ or as alkali sulfates. The calcined raw material is transported by the rotational movement and slight inclination of the rotary kiln toward the hot burning zone, where flame temperatures are in the range of $2000{ }^{\circ} \mathrm{C}$ and material temperatures are around $1450{ }^{\circ} \mathrm{C}$. The clinker reactions take place during the gradual heating of the calcined raw material as it is transported through the rotary kiln. During the gradual heating of the calcined raw material, a sulfate melt is formed that facilitates formation of alkali sulfates, $\mathrm{Na}_{2} \mathrm{SO}_{4}$ and $\mathrm{K}_{2} \mathrm{SO}_{4}$, which are more thermodynamically stable than $\mathrm{CaSO}_{4} \cdot{ }^{3} \mathrm{CaSO}_{4}$ will decompose at the high temperatures present in the burning zone and form $\mathrm{SO}_{2}$ or alkali sulfates.

The main challenge with respect to alternative fuel utilization in the material inlet end of rotary kilns is that solid fuel particles will be in physical contact with the calcined raw material: During the fuel devolatilization, reducing agents such as $\mathrm{CO}, \mathrm{H}_{2}$, and/or hydrocarbons are formed. These reducing species may react with elements in the calcined raw material before they are oxidized to their ultimate combustion products, $\mathrm{H}_{2} \mathrm{O}$ and $\mathrm{CO}_{2}$. In addition, if the fuel particles are fully or partly covered by calcined raw material, mass transfer of oxygen to the fuel char will be hindered. Substoichiometric amounts of oxygen will lead to incomplete oxidation of the fuel char, forming reducing agents in the form of $\mathrm{CO}, \mathrm{H}_{2}$, and/or hydrocarbons. The process stability of the kiln system may be affected by increased release of sulfur from the calcined raw material, mainly by reductive decomposition of $\mathrm{CaSO}_{4}$ :

$$
\mathrm{CaSO}_{4}(\mathrm{~s})+\mathrm{CO}(\mathrm{g}) \leftrightarrow \mathrm{CaO}(\mathrm{s})+\mathrm{CO}_{2}(\mathrm{~g})+\mathrm{SO}_{2}(\mathrm{~g})
$$

Increasing amounts of $\mathrm{SO}_{2}$ in the cement kiln system is problematic because $\mathrm{SO}_{2}$ promotes formation of sulfospurrite $\left(2\left(2 \mathrm{CaO} \cdot \mathrm{SiO}_{2}\right) \cdot \mathrm{CaSO}_{4}\right)$ and calcium sulfoaluminate $\left(3 \mathrm{CaO} \cdot 3 \mathrm{Al}_{2} \mathrm{O}_{3} \cdot \mathrm{CaSO}_{4}\right)$, some of the principal constituents of deposit buildups found in rotary kilns and kiln riser ducts. ${ }^{4}$

$\begin{array}{ll}\text { Received: } & \text { July 1, 2011 } \\ \text { Revised: } & \text { August 15, } 2011 \\ \text { Published: } & \text { August 15, } 2011\end{array}$

Revised: August 15, 2011

Published: August 15, 2011 


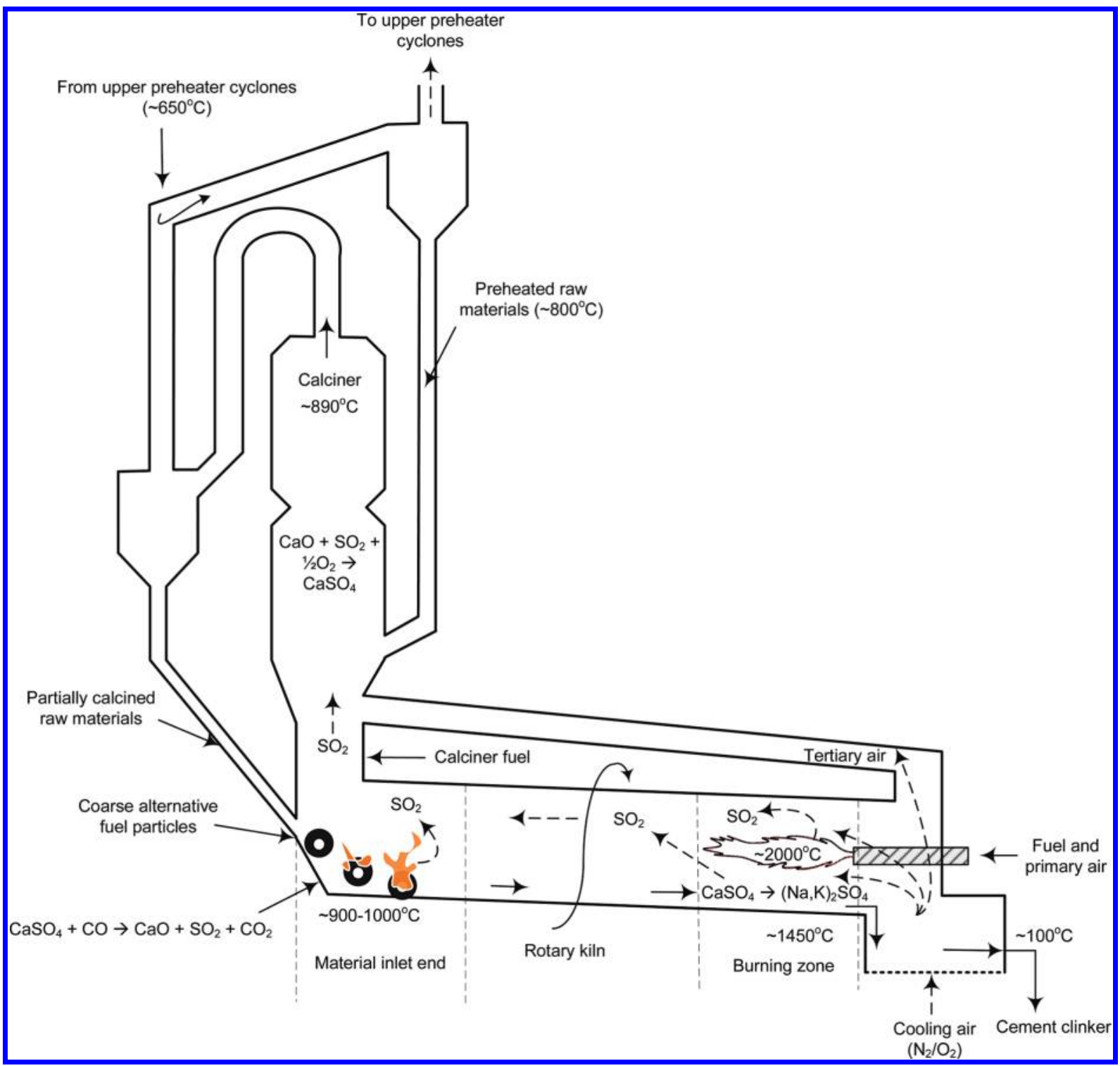

Figure 1. Illustration of alternative fuel utilization in the material inlet end of a cement rotary kiln. The calciner and two lowest preheater cyclones are also shown.

These sulfur-containing deposits can lead to blockages that need to be removed, sometimes by a temporary plant shutdown.

Relatively little information is available in the literature about $\mathrm{SO}_{2}$ release from cement raw materials during utilization of solid fuels. However, adsorption and release of $\mathrm{SO}_{2}$ for the $\mathrm{SO}_{2}-$ $\mathrm{CaO}-\mathrm{CaSO}_{4}-\mathrm{CaS}-\mathrm{CO}-\mathrm{CO}_{2}$ system under fluidized bed conditions has been studied extensively during the last decades. ${ }^{5-11}$ Even though these investigations are not directly applicable to describe the conditions in the material inlet end of cement rotary kilns, they do include relevant descriptions of mechanisms for $\mathrm{SO}_{2}$ release and capture by limestone at temperatures up to $1200{ }^{\circ} \mathrm{C}$ and under oxidizing as well as reducing atmospheres.

Hansen et al. ${ }^{9,10}$ studied phase equilibria for the $\mathrm{SO}_{2}-\mathrm{CaO}-$ $\mathrm{CaSO}_{4}-\mathrm{CaS}-\mathrm{CO}-\mathrm{CO}_{2}$ system. They performed experiments in an electrically heated laboratory scale fixed bed reactor developed to simulate the changing oxidizing and reducing conditions similar to the conditions particles will experience in a fluidized bed reactor. They found that any transformation between $\mathrm{CaSO}_{4}$ and $\mathrm{CaS}$ takes place via $\mathrm{CaO}$. This competition

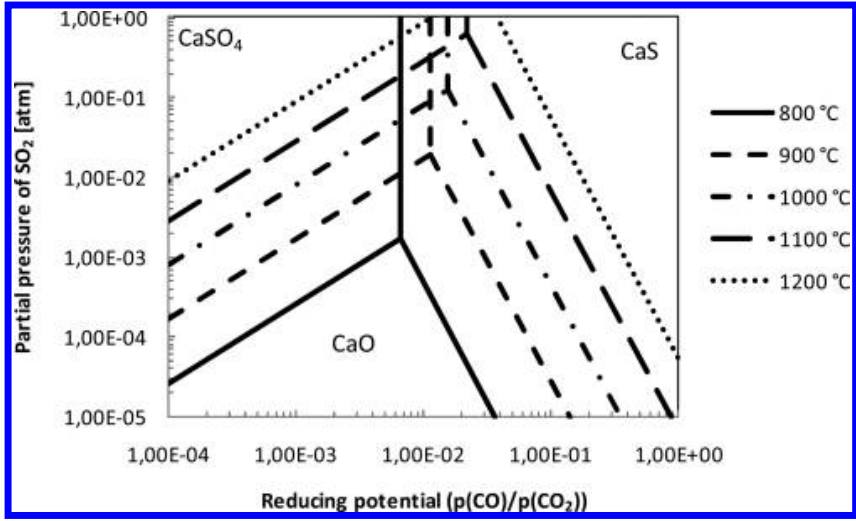

Figure 2. Phase diagram for the $\mathrm{SO}_{2}-\mathrm{CaO}-\mathrm{CaSO}_{4}-\mathrm{CaS}-\mathrm{CO}-\mathrm{CO}_{2}$ system (based on thermochemical data from Barin). ${ }^{12}$

between sulfur capture and sulfur release depends on parameters such as partial pressures of $\mathrm{SO}_{2}, \mathrm{CO}$, and $\mathrm{CO}_{2}$ (see the equilibrium 


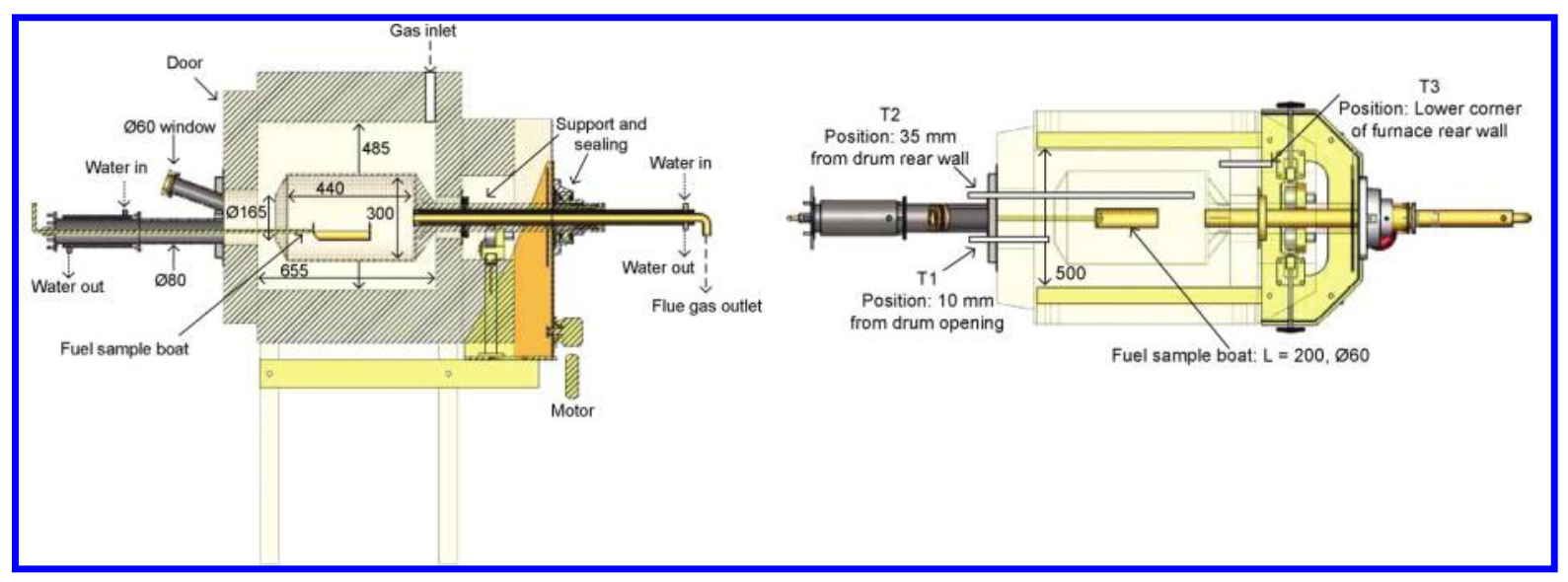

Figure 3. High-temperature rotary drum: (left) side view and (right) top view.

phase diagram in Figure 2). Temperature is a very important parameter: An increase in temperature in the interval 800$1200{ }^{\circ} \mathrm{C}$ will shift the equilibrium toward $\mathrm{CaO}$ and release more $\mathrm{SO}_{2}{ }^{9} \cdot$

The aim of this work is to obtain quantitative data on the release of $\mathrm{SO}_{2}$ from calcined cement raw materials under conditions that resemble those in the material inlet end of rotary kilns. The purpose is to document the impact on $\mathrm{SO}_{2}$ release during utilization of solid alternative fuels, in the material inlet end of cement rotary kilns.

\section{EXPERIMENTAL SECTION}

The purpose of the experiments is to clarify how the sulfur release in the form of $\mathrm{SO}_{2}$ is affected by different solid fuels and reaction conditions. The release of sulfur from cement raw materials as a function of fuel type and fuel characteristics was quantified in the temperature interval from 700 to $1000{ }^{\circ} \mathrm{C}$ and at oxygen concentrations from 5 to $21 \mathrm{vol} \%$. The temperature interval and oxygen concentrations up to $10 \mathrm{vol} \%$ resemble realistic material temperatures and atmospheres in the material inlet end of cement rotary kilns. The used cement raw materials were based on a synthetic mixture of quartz sand and $5 \mathrm{wt} \%$ calcium sulfate, $\mathrm{CaSO}_{4}$. This represents a simplified batch of cement raw material entering the rotary kiln, with a high, but realistic, sulfur content.

Experimental Setup. The experiments were made in a hightemperature rotary drum in a commercially available chamber furnace (see Figure 3). The setup can reach an operating temperature of $1000{ }^{\circ} \mathrm{C}$. It is electrically heated by heating elements embedded in two side walls and the floor. The steel drum is supported by a steel tube on rollers that passes through the rear wall. This steel tube is connected to a motor by means of a roller chain, in order to rotate the drum. The part of the steel tube that is outside the chamber furnace is water cooled in order to protect the rollers, roller chain, and gas seals against the high temperatures.

Gas can be transported to the chamber furnace through a hole in the roof. The furnace has been designed to achieve sufficient heating of the reactant gas before it enters the rotary drum; this was verified by temperature measurements. The gas is transported into the rotating steel drum due to an externally placed gas pump that pumps the gas through the rotating drum and steel tube, after which the gas exits the reactor for subsequent cooling and analysis.

The chamber furnace door is equipped with a window for visual inspection, two holes for thermocouples, and a centrally placed watercooled tube for solid fuel addition. The solid fuels are placed in a sample container that can be pushed into the hot rotary drum or pulled out to the water-cooled tube.
The experimental setup is shown in Figure 4. The gas supply can be up to $500 \mathrm{NL} / \mathrm{min}$ of air and nitrogen. The gas is transported to the rotary drum reactor during the experiments, but may also be bypassed during calibration of flow controllers, leakage tests, etc.

The temperature is measured in three different positions in the rotary drum reactor: at the rear wall in the chamber furnace (T1), in the center of the rotary drum (T2), and at the door just in front of the rotary drum (T3). A pump transports the flue gas out of the rotary drum reactor. Before passing the pump, the flue gas is cooled in a heat exchanger, and soot particles are captured in a filter. After having passed the pump, the flue gas is sent directly either to the stack or to the gas analyzers for measurement of $\mathrm{O}_{2}, \mathrm{CO}, \mathrm{CO}_{2}, \mathrm{SO}_{2}$, and $\mathrm{NO}$. The fraction of the flue gas that is transported to the analyzers will pass another two filters, a gas cooler for condensation of water, and a sample gas pump before reaching the gas analyzers.

Materials and Methods. A $2.5 \mathrm{~kg}$ portion of raw material in the form of quartz sand with $5 \mathrm{wt} \% \mathrm{CaSO}_{4}$ is placed in the rotary drum. This corresponds to a volumetric fill degree of $5 \%$. The drum is rotated at $6 \mathrm{rpm}$ in order to keep the raw material in a continuous rolling motion. The raw materials are then preheated to the desired temperature, in the interval from 700 to $1000^{\circ} \mathrm{C}$. A constant flow of $100 \mathrm{NL} / \mathrm{min}$ of gas with the desired oxygen concentration is transported through the rotary drum and will pass over the raw materials in the lower part of the rotary drum. The gas is preheated to the same temperature as the raw materials in order to obtain a uniform temperature at all positions. The temperature and oxygen concentration are monitored continuously, and when these have stabilized, a batch of solid fuel is rapidly added into the raw materials in the rotary drum. $\mathrm{SO}_{2}, \mathrm{NO}, \mathrm{O}_{2}, \mathrm{CO}$, and $\mathrm{CO}_{2}$ concentrations are measured during the devolatilization and char combustion. The gas composition is logged for subsequent evaluation of the sulfur release. In all experiments, the sulfur release was measured by integrating the $\mathrm{SO}_{2}$ signal over time:

$$
m_{\text {sulfur }}=\int_{0}^{t} y_{\mathrm{SO}_{2}} \mathrm{~d} t \times 10^{-6} \times \mathrm{MW}_{\text {sulfur }} \times \frac{P V}{R T}
$$

where $y_{\mathrm{SO}_{2}}$ is the mole fraction in ppmV, $\mathrm{MW}_{\text {sulfur }}$ is the molar weight of sulfur in $\mathrm{g} / \mathrm{mol}$, and $V$ is the gas flow in $\mathrm{L} / \mathrm{s}$.

Since many of the fuels contain sulfur that will also be released during the experiments, baseline experiments have been made, where the fuels are combusted in $2.5 \mathrm{~kg}$ of pure quartz sand, without $\mathrm{CaSO}_{4}$. The measured $\mathrm{SO}_{2}$ from the baseline experiments can only arise from the fuels and not from the raw material. The amount of sulfur released during the baseline experiments is subtracted from the sulfur released during the actual experiment in order to get the corrected accumulated amount of sulfur that arises from the raw material. 


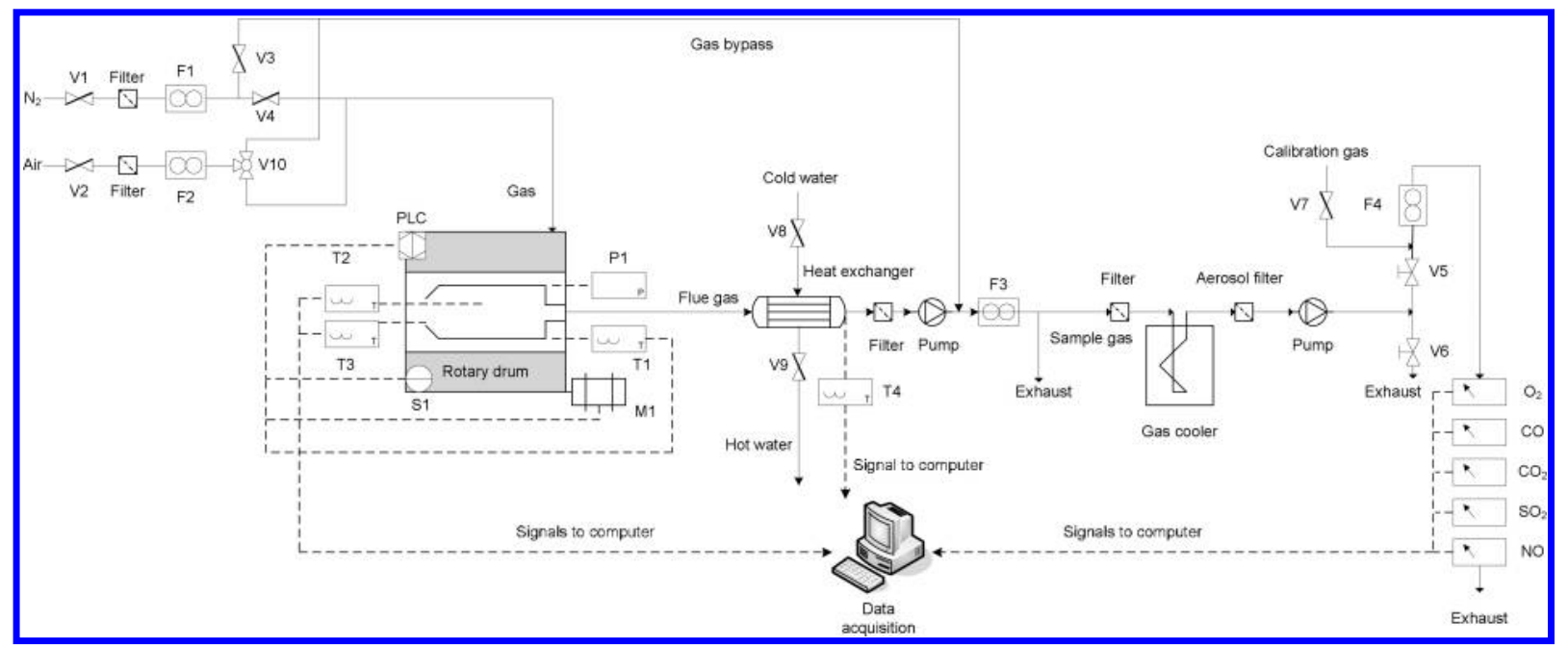

Figure 4. Sketch of the high-temperature rotary drum experimental setup.

Table 1. Fuel Analyses and Lower Heating Values (LHV) for Solid Fuels Used in the Experiments

\begin{tabular}{|c|c|c|c|c|c|c|c|c|}
\hline & \multicolumn{3}{|c|}{ proximate analysis $^{a}$} & \multicolumn{4}{|c|}{ ultimate analysis $^{a}$} & \multirow[b]{2}{*}{$\mathrm{LHV}(\mathrm{MJ} / \mathrm{kg})$} \\
\hline & $\mathrm{VM}$ & FC & ash & $\mathrm{C}$ & $\mathrm{H}$ & $\mathrm{N}$ & S & \\
\hline tire rubber & 64.6 & 32.6 & 2.8 & 87.4 & 7.1 & 0.3 & 1.2 & 36.9 \\
\hline pine wood & 75.3 & 24.5 & 0.2 & 38.9 & 5.2 & 0.1 & - & 16.2 \\
\hline polypropylene & 97.5 & 0.0 & 2.5 & 83.0 & 14.0 & 0.0 & - & 44.5 \\
\hline petcoke & 13.4 & 85.1 & 1.5 & 87.3 & 3.7 & 1.5 & 4.7 & 34.0 \\
\hline sewage sludge & 49.3 & 0.5 & 50.2 & 29.0 & 3.8 & 3.8 & 1.0 & 12.5 \\
\hline
\end{tabular}

Table 2. Approximate Shapes and Dimensions of the Fuels Used in the Experiments

\begin{tabular}{lll}
\multicolumn{1}{c}{ fuel } & \multicolumn{1}{c}{ shape } & \multicolumn{1}{c}{ dimensions } \\
tire rubber granulate & irregular & $D_{\mathrm{p}} \approx 2 \mathrm{~mm}$ \\
tire rubber cylinders & cylindrical & $L=12 \mathrm{~mm}, D_{\mathrm{p}}=9 \mathrm{~mm}$ \\
pine wood cubes & rectangular & thickness $\approx 10 \mathrm{~mm}$ \\
pine wood sawdust & needles & thickness $\approx 1 \mathrm{~mm}$ \\
polypropylene flakes & rectangular & thickness $\approx 1 \mathrm{~mm}$ \\
petcoke & spherical & $D_{\mathrm{p}} \approx 1 \mathrm{~mm}$ \\
sewage sludge & spherical & $D_{\mathrm{p}} \approx 0.5 \mathrm{~mm}$ \\
\hline
\end{tabular}

All experiments were repeated at least two times to ensure the repeatability. The sulfur release values reported in the figures are the average values from the experiments, corrected for the sulfur contribution from the fuels.

Five different solid fuels have been tested: tire rubber, pine wood, polypropylene, petcoke, and sewage sludge. In order to compare the sulfur release between fuels, the amount of fuel is chosen to obtain the same energy input. Fuel proximate and ultimate analyses as well as lower heating values are shown in Table 1 . The lower heating values for the fuels are quite different. Thus, quite different fuel sample amounts have been used in order to have the same energy input in each experiment, regardless of the fuel. The energy input during the experiments was chosen to be in the interval $15-50 \mathrm{~kJ}$ per batch, corresponding to fuel sample sizes from 0.3 to $4.2 \mathrm{~g}$. These energy inputs were chosen to obtain a suitable level of sulfur release, thereby avoiding $\mathrm{SO}_{2}$ peaks exceeding the analyzer range.

Several different fuel particle sizes and shapes have been used in the experiments, and these are presented in Table 2.

Assumptions, Limitations, and Uncertainties. This section discusses important assumptions, limitations, and uncertainties that may influence the obtained results.

(1) The temperature at which the experiment is conducted is determined as the measured temperature in the center of the rotary drum, above the raw material charge. It is assumed that the gas temperature and raw material temperature is the same at all positions in the rotary drum. Temperature profiles have been measured at various positions in the rotary drum, and the temperature was found to deviate no more than $\pm 15^{\circ} \mathrm{C}$.

(2) The experiments are conducted in the temperature interval from 700 to $1000{ }^{\circ} \mathrm{C}$, whereas the raw material and gas temperatures in the material inlet end of modern industrial cement rotary kilns are typically $900{ }^{\circ} \mathrm{C}$ and $1000-1200{ }^{\circ} \mathrm{C}$, respectively. The temperature interval is thus only partly representative for the industrial conditions. However, it is not possible to conduct experiments above $1000^{\circ} \mathrm{C}$ in the present experimental setup.

(3) The gas passing through the rotary drum is pure mixtures of $\mathrm{N}_{2}$ and $\mathrm{O}_{2}$. During the devolatilization and char combustion, a fraction of the $\mathrm{O}_{2}$ will be consumed, and the combustion products $\mathrm{H}_{2} \mathrm{O}, \mathrm{NO}, \mathrm{SO}_{2}, \mathrm{CO}$, and $\mathrm{CO}_{2}$ will be formed. In addition, some intermediate products such as $\mathrm{CH}_{4}$ or higher hydrocarbons, alkali species, etc. may be formed. Under industrial conditions, the gas will also contain the combustion products from the main kiln burner and may have overall gas compositions different from the one used in these experiments. This difference in gas composition is likely to affect the sulfur release to some extent.

(4) The uncertainty on the $\mathrm{O}_{2}, \mathrm{CO}$, and $\mathrm{CO}_{2}$ analyzers are $\pm 2 \%$ of span range for each species, while it is $\pm 5 \%$ on the $\mathrm{SO}_{2}$ measurement. These uncertainties should be kept in mind when the results are evaluated.

(5) It is assumed that all sulfur released from the sample will be oxidized to $\mathrm{SO}_{2}$ before leaving the reactor. This assumption is supported by equilibrium calculations with the thermodynamics software FactSage, which predicts that nearly all sulfur is present as $\mathrm{SO}_{2}$ under the studied conditions. ${ }^{2}$

(6) The physical shape of the rotary drum reactor may cause a diffusion limitation of oxygen to the fuel particles, since oxygen must be transported from the drum center line to the fully or partly 


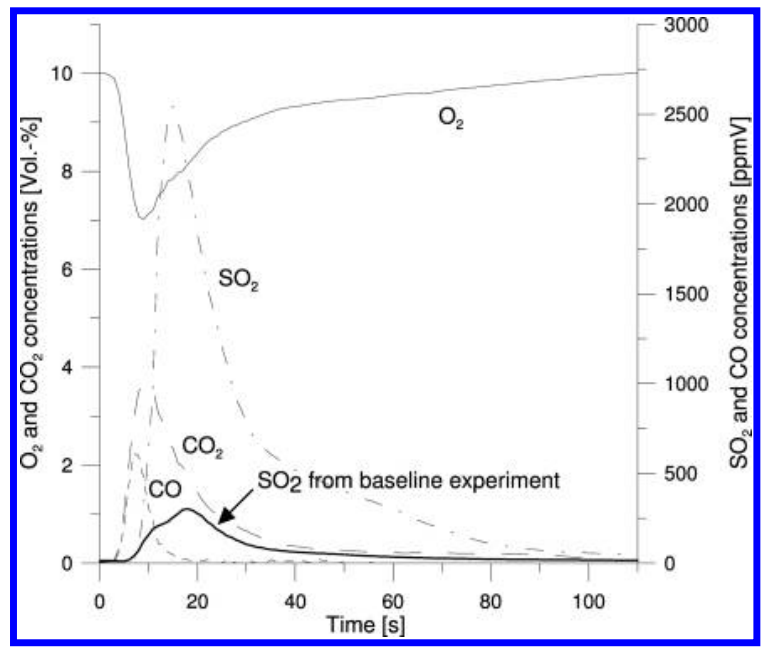

Figure 5. Concentrations of $\mathrm{O}_{2}, \mathrm{CO}_{2}, \mathrm{CO}$, and $\mathrm{SO}_{2}$ during an experiment with $0.81 \mathrm{~g}$ of tire rubber granulate corresponding to an energy input of $30 \mathrm{~kJ}$. Conditions: $900{ }^{\circ} \mathrm{C}, 5 \%$ fill, $6 \mathrm{rpm}, 100 \mathrm{NL} / \mathrm{min}, 10 \% \mathrm{O}_{2}$.

buried fuel particles in the raw material bed. However, since all experiments are made under similar conditions, it is assumed that results will be comparable.

(7) The flue gas composition will not change significantly in the distance between the reactor and the analyzers. To minimize this uncertainty and prevent, for example, $\mathrm{SO}_{2}$ absorption in filters and condensers, these parts were regularly cleaned or replaced to minimize the presence of compounds able to absorb $\mathrm{SO}_{2}$. A gas with known content of $\mathrm{SO}_{2}$ was also regularly sent through the system to test if any $\mathrm{SO}_{2}$ was absorbed before reaching the analyzers.

\section{RESULTS AND DISCUSSION}

General Observations. Figure 5 shows an example of the flue gas composition during combustion of tire rubber granulate at an initial oxygen concentration of $10 \mathrm{vol} \%$. When the devolatilization starts, the $\mathrm{O}_{2}$ concentration drops to approximately $7 \mathrm{vol} \%$ and the $\mathrm{CO}_{2}$ concentration increases to nearly $4 \mathrm{vol} \%$. The $\mathrm{CO}$ concentration also increases shortly to around $600 \mathrm{ppm}$. The change in flue gas composition is followed by a rapid increase in the $\mathrm{SO}_{2}$ concentration from $0 \mathrm{ppm}$ to around $2500 \mathrm{ppm}$. The $\mathrm{SO}_{2}$ concentration then gradually decreases toward $0 \mathrm{ppm}$ again, as the $\mathrm{CO} / \mathrm{CO}_{2}$ concentrations gradually decrease.

The sulfur release from the tire rubber and raw material is observed to begin almost immediately during the fuel heat up and devolatilization. Baseline experiments with fuel combustion in pure quartz sand without $\mathrm{CaSO}_{4}$ shows that only a minor fraction of the sulfur release arises from fuel-bound sulfur; most of the sulfur is released from the raw materials, which is also shown in Figure 5. The sulfur release is presumably facilitated by the formation of local reducing conditions near the raw material charge during the fuel devolatilization, leading to reductive decomposition of $\mathrm{CaSO}_{4}$. The tendency for a rapid sulfur release during the fuel devolatilization was observed for all experiments regardless of the fuel.

Effect of Energy Input and Fuel Type. The sulfur release from the raw material as a function of the energy input has been studied for five different fuels at $900{ }^{\circ} \mathrm{C}$ and 10 vol \% oxygen. The fuels were polypropylene flakes, petcoke, pine wood sawdust, tire rubber granulate, and sewage sludge (see Tables 1 and 2 for details). These fuels all have relatively similar average particle

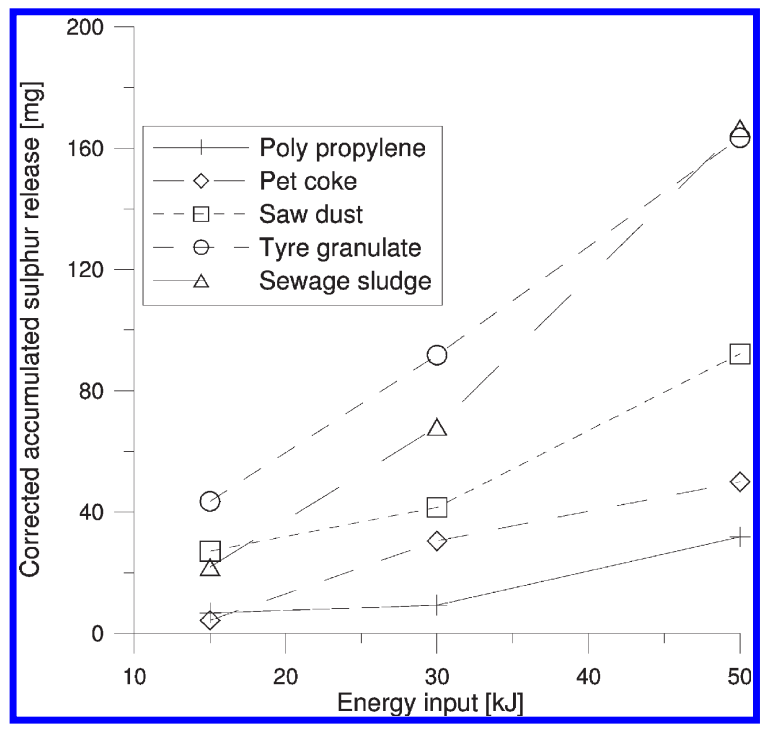

Figure 6. Corrected accumulated sulfur release as a function of energy input from different fuels. Conditions: $900{ }^{\circ} \mathrm{C}, 10 \mathrm{vol} \% \mathrm{O}_{2}, 5 \%$ fill, 100 $\mathrm{NL} / \mathrm{min}, 6 \mathrm{rpm}$.

thicknesses in the interval $0.5-2.0 \mathrm{~mm}$. The results are shown in Figure 6. For all tested fuels it is observed that the sulfur release from the raw materials increases as the energy input increases. It is also observed that the sulfur release is quite different depending on the specific fuel: tire rubber granulate and sewage sludge leads to the highest sulfur release, while pine wood, petcoke, and polypropylene all leads to a lower sulfur release.

The reason why the sulfur release increases with increasing energy input becomes clear when the flue gas compositions at each individual experiment are compared with each other: The larger the energy input, the more the oxygen concentration will decrease during the fuel devolatilization, while both $\mathrm{CO}$ and $\mathrm{CO}_{2}$ concentrations increase, thereby forming a higher degree of reducing conditions near the raw material charge.

The large differences in sulfur release for identical energy inputs but by different fuels are interesting. A detailed study of the flue gas composition for each fuel type has not revealed any clear trends about the degree of reducing conditions and sulfur release. The reason is probably that the exact particle sizes, shapes, densities, fuel combustion pathways, and kinetics of the studied fuels are quite different and that this also has an effect on sulfur release. The approximately spherical tire rubber granulate and sewage sludge particles may for example lead to a high sulfur release because of a relatively fast devolatilization combined with a high degree of mixing with the raw material. The needle-shaped sawdust particles yield a lower sulfur release than tire rubber granulate and sewage sludge, even though the sawdust also has a fast devolatilization. An explanation could be that the sawdust particles are less dense than the tire rubber and sewage sludge and that the density difference leads to a low degree of mixing of sawdust into the raw material. The polypropylene flakes have the lowest sulfur release, which may be explained by a very fast devolatilization, so fast that the polypropylene devolatilization ends before it has been well mixed into the raw material. Finally, the small petcoke particles are a slow burning fuel with a volatile content of only $13 \%$. This leads to a relatively small decrease in oxygen concentration during the fuel conversion compared to 


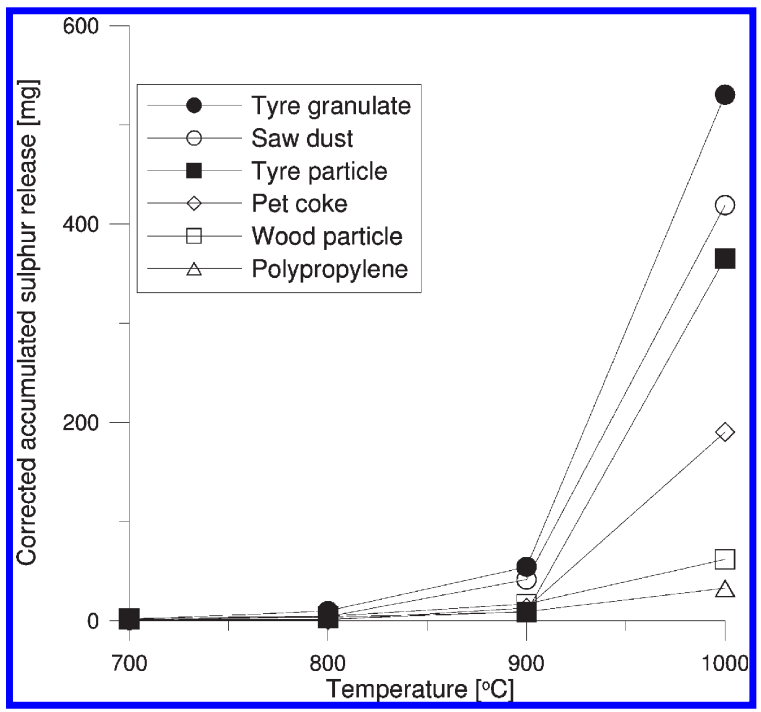

Figure 7. Corrected accumulated sulfur release from raw materials as a function of temperature and fuel particle size. Conditions: $5 \%$ fill degree, $10 \mathrm{vol} \% \mathrm{O}_{2}, 100 \mathrm{NL} / \mathrm{min}, 6 \mathrm{rpm}$. Energy input in each experiment: $30 \mathrm{~kJ}$. Sulfur release for tire granulate and sawdust at $1000^{\circ} \mathrm{C}$ has been estimated because the $\mathrm{SO}_{2}$ concentration exceeded the analyzer range for these two specific experiments.

the other fuels and thereby a low degree of local reducing conditions near the raw material bed.

Effect of Temperature and Fuel Particle Size. The sulfur release is studied as a function of the temperature and fuel particle size, which are both important for the devolatilization and char combustion times. Tire rubber and pine wood are used in the investigations about particle size while the investigations about temperature also include petcoke and polypropylene. The tire rubber is fed as cylinders or tire rubber granulates, while the pine wood is in the form of one pine wood particle or as sawdust. The overall energy input is the same in each experiment. Details about the fuels can be found in Tables 1 and 2. The results are shown in Figure 7 with sulfur release in milligrams versus temperature for the different fuel particle sizes. It is observed that the fuel particle size is insignificant for the sulfur release at 700 and $800{ }^{\circ} \mathrm{C}$, while the influence becomes more evident at $900^{\circ} \mathrm{C}$ and, in particular, at $1000^{\circ} \mathrm{C}$ : At 900 and $1000^{\circ} \mathrm{C}$ the sawdust and tire granulate lead to a higher sulfur release than for the wood particle and tire particle.

The significant effect of temperature on the sulfur release was also to be expected due to the lower thermal stability of $\mathrm{CaSO}_{4}$ at higher temperatures (see the phase diagram in Figure 2). In addition, comparison of the flue gas compositions during the combustion at different temperatures shows that the $\mathrm{CO}$ concentration during the fuel devolatilization reaches higher values at higher temperatures than at lower temperatures. This can be attributed to be a faster release of volatiles from the fuel particles at elevated temperatures, thereby increasing the tendency for local reducing conditions in the area around the fuel particles. Local reducing conditions will augment the sulfur release during the fuel devolatilization.

The reason for the difference in sulfur release for different fuel particle sizes becomes clear when the flue gas composition is studied for the individual experiments: The larger total surface areas of the smaller fuel particles leads to a fast devolatilization and thus a fast release of volatiles. This leads to significantly

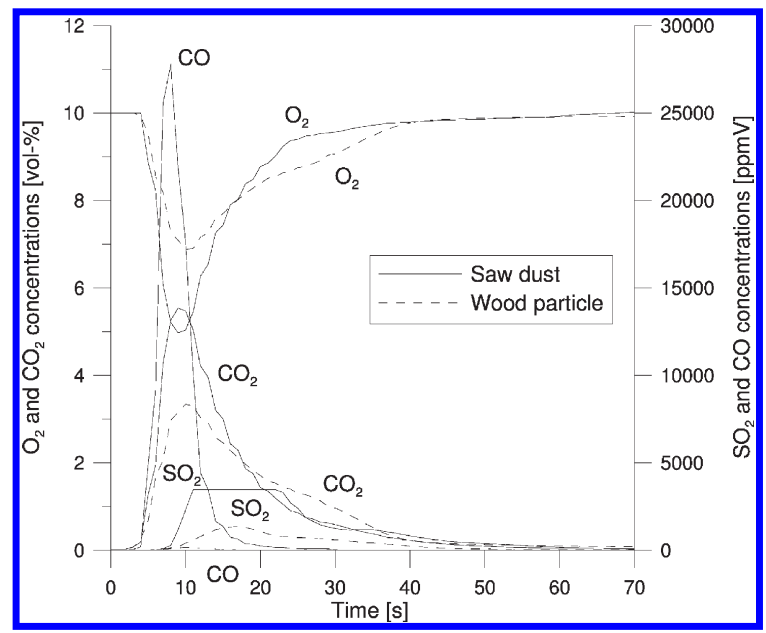

Figure 8. Flue gas composition during combustion of a pine wood particle with dimensions $30 \times 15 \times 10 \mathrm{~mm}$ and pine wood sawdust with particle size $<1 \mathrm{~mm}$. Conditions: $10 \mathrm{vol} \% \mathrm{O}_{2}, 5 \%$ fill degree, $1000^{\circ} \mathrm{C}, 100 \mathrm{NL} / \mathrm{min}, 6 \mathrm{rpm}$.

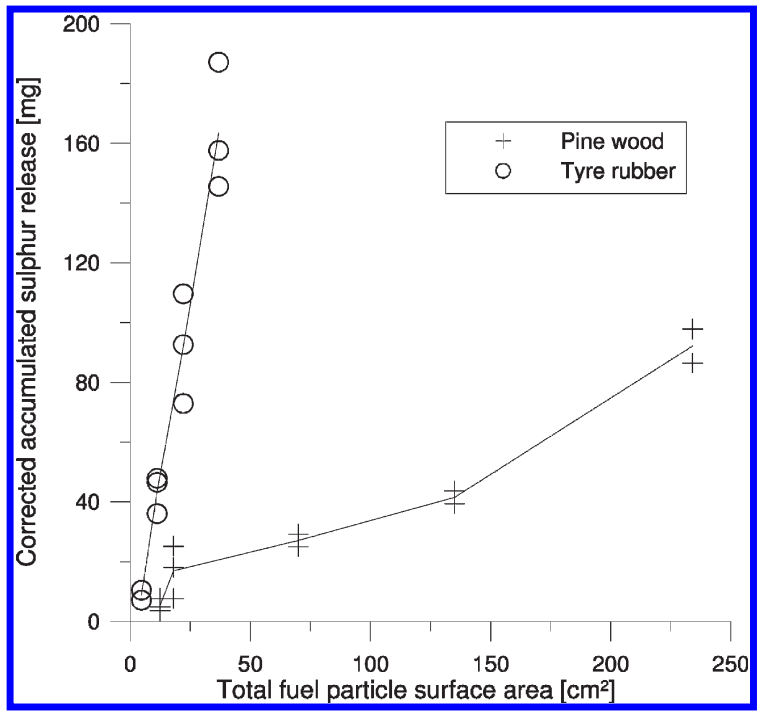

Figure 9. Corrected accumulated sulfur release versus the total surface area of pine wood and tire rubber fuel particles. Conditions: $900{ }^{\circ} \mathrm{C}$, $10 \mathrm{vol} \% \mathrm{O}_{2}, 5 \%$ fill degree, $6 \mathrm{rpm}, 100 \mathrm{NL} / \mathrm{min}$.

higher $\mathrm{CO}$ concentrations and thus a higher reductive decomposition of $\mathrm{CaSO}_{4}$ during the devolatilization. An example is illustrated in Figure 8, which shows flue gas compositions during wood particle and sawdust combustion, respectively, at $1000{ }^{\circ} \mathrm{C}$. During wood particle combustion, the $\mathrm{CO}$ peak during devolatilization reaches $180 \mathrm{ppm}$ and the $\mathrm{SO}_{2}$ peak reaches $1350 \mathrm{ppm}$. During sawdust combustion, the $\mathrm{CO}$ peak is significantly larger and reaches 27000 ppm $(2.7 \mathrm{vol} \%)$ which leads to a $\mathrm{SO}_{2}$ peak well above the analyzer detection range of $3500 \mathrm{ppm}$. The changes in $\mathrm{O}_{2}$ concentration are from the initial 10 to $5 \mathrm{vol} \%$ for the sawdust and to $7 \mathrm{vol} \%$ for the pine wood particle. Similar trends were observed for the experiments with one tire particle versus tire granulate.

Since the experiments with sawdust and tire granulate at $1000{ }^{\circ} \mathrm{C}$ led to $\mathrm{SO}_{2}$ peaks well above the $\mathrm{SO}_{2}$ analyzer range, it has been necessary to estimate the total sulfur release from these two experiments. This induces some uncertainty on the exact amount of released sulfur in these two cases at $1000{ }^{\circ} \mathrm{C}$. 


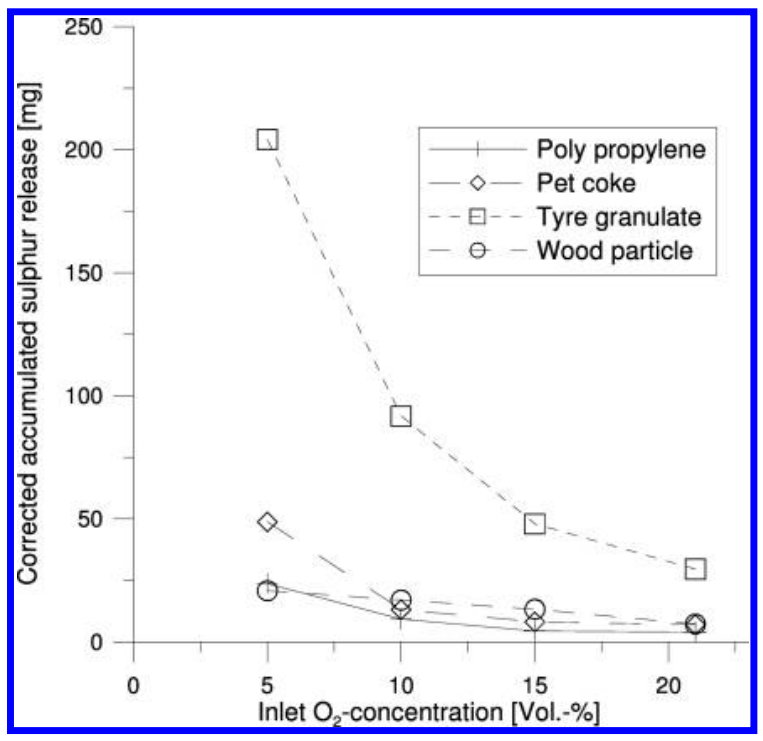

Figure 10. Corrected accumulated sulfur release as a function of inlet oxygen concentration for four different fuels. Conditions: $5 \%$ fill degree, $900^{\circ} \mathrm{C}, 100 \mathrm{NL} / \mathrm{min}, 6 \mathrm{rpm}$. Energy input in each experiment was $30 \mathrm{~kJ}$.

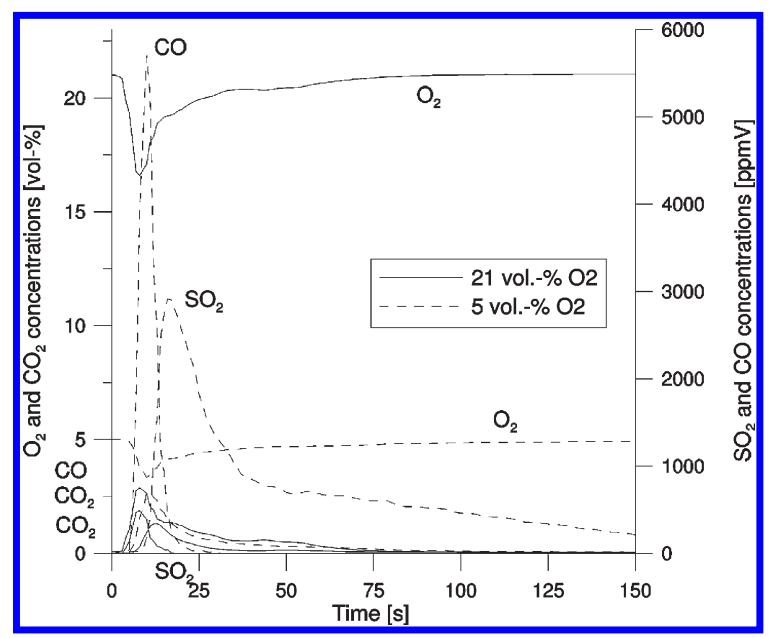

Figure 11. Flue gas composition during combustion of $0.81 \mathrm{~g}(30 \mathrm{~kJ})$ of tire rubber granulate at 5 and $21 \mathrm{vol} \% \mathrm{O}_{2}$. Conditions: $5 \%$ fill degree, $900{ }^{\circ} \mathrm{C}, 100 \mathrm{NL} / \mathrm{min}, 6 \mathrm{rpm}$.

Figure 9 shows the sulfur release versus the total surface area of the tire rubber and pine wood fuel particles at $900{ }^{\circ} \mathrm{C}$. The sulfur release is observed to increase approximately linearly as a function of surface area for tire rubber. It should be noted that the fuel mass, and thus energy input, also increases when the surface area increases. This increase in sample mass will also lead to more sulfur release, as shown in Figure 6. The sulfur release for pine wood is less significant than for tire rubber but also may also be characterized as linear as a function of surface area.

Effect of Bulk Oxygen Concentration. The sulfur release has been studied as a function of the inlet oxygen concentration in the freeboard gas above the raw material bed. The investigation has been conducted with polypropylene, petcoke, pine wood cubes, and tire rubber granulate (see Table 1 for details). The results are shown in Figure 10 with the sulfur release expressed in milligrams of pure sulfur versus the oxygen concentration expressed in volume percent. It is observed that the sulfur release increases for all tested fuels when the oxygen concentration decreases. Particularly, the tire rubber granulate leads to an increase in sulfur release of nearly a factor 8 when the oxygen concentration changes from 21 to $5 \mathrm{vol} \% \mathrm{O}_{2}$.

The reason for the high dependency of the oxygen concentration on the sulfur release becomes clear when the changes in flue gas composition are considered. Figure 11 shows the combustion of tire rubber granulate at 21 and 5 vol \%, respectively. It is observed that the $\mathrm{CO}$ and $\mathrm{SO}_{2}$ concentrations reaches approximately 500 and $350 \mathrm{ppm}$, respectively, at 21 vol \% $\mathrm{O}_{2}$, while the $\mathrm{CO}$ and $\mathrm{SO}_{2}$ concentrations reach approximately 5700 and $2900 \mathrm{ppm}$, respectively, at $5 \mathrm{vol} \% \mathrm{O}_{2}$. Thus, the formation of the reducing agent $\mathrm{CO}$ is accompanied by a reductive decomposition of $\mathrm{CaSO}_{4}$ to $\mathrm{SO}_{2}$, and the degree of this reductive decomposition is directly related to the $\mathrm{CO}$ concentration. The same trend was observed for the other tested fuels.

\section{CONCLUSIONS}

Sulfur release from cement raw materials during combustion of solid fuels has been studied experimentally in a high-temperature rotary drum experimental setup. The fuels were tire rubber, pine wood, petcoke, sewage sludge, and polypropylene. The sulfur release from the raw materials was observed to increase when (a) the inlet oxygen concentration decreased, (b) the temperature increased, and/or (c) the total surface area of the fuel particles increased. These three parameters all had the potential of augmenting local reducing conditions in the raw material bed, as indicated by elevated levels of $\mathrm{CO}$ during the fuel devolatilization. The sulfur release increased as a consequence of the reducing conditions, due to the lower stability of $\mathrm{CaSO}_{4}$.

The type of fuel also had a significant effect on the sulfur release. The sequence was found to be tire rubber granulate $>$ sewage sludge $>$ pine wood sawdust $>$ petcoke $>$ polypropylene flakes. However, the sulfur release was significantly lower when the fuel was one tire rubber particle or one wood particle, indicating that fuel particle size has a great effect on the sulfur release from the raw materials.

In order to minimize sulfur release from cement raw materials during solid fuel combustion in the material inlet end of the rotary kiln, it is recommended to have as high a bulk oxygen concentration as possible. This could for example be achieved by a high excess air ratio in the rotary kiln main burner. The temperature of the cement raw materials should be kept as low as possible during the fuel devolatilization. This can be achieved by introducing partially calcined raw materials from the calciner rather than completely calcined raw materials: The very endothermic calcination process can absorp heat from the fuels, thereby helping to maintain a relatively low bed temperature during fuel devolatilization in the rotary kiln material inlet. Finally, use of coarse fuel particles can slow the fuel devolatilization rate and thereby the rapid formation of reducing agents. Thus, use of coarse fuel particles in the material inlet end of cement rotary kilns is likely to reduce the tendency for local reducing conditions relative to the situation with fine fuel particles.

\section{AUTHOR INFORMATION}

\section{Corresponding Author}

*E-mail: arn@kt.dtu.dk. Telephone: +45 45252831.

\section{ACKNOWLEDGMENT}

The work described in this paper is part of a research platform on future cement technology financed by The Danish National 
Advanced Technology Foundation, Technical University of Denmark (DTU) and FLSmidth A/S.

\section{REFERENCES}

(1) Verein Deutscher Zementwerke (VDZ), Activity Report 20072009, Düsseldorf, Germany, http://www.vdz-online.de. Obtained July $1,2011$.

(2) Nielsen, A. R.; Larsen, M. B.; Glarborg, P.; Dam-Johansen, $\underline{\text { K. }}$ Energy Fuels 2011, 25, 2917-2926.

(3) Choi, G.-S.; Glasser, F. P. Cem. Concr. Res. 1988, 18, 367-374.

(4) Sylla, H.-M. ZKG 1974, 10, 499-508.

(5) Hansen, J. P. $\mathrm{SO}_{2}$ Emissions from Cement Production. Ph.D. Thesis, Technical University of Denmark, Department of Chemical Engineering, 2003; ISBN 87-90142-96-9.

(6) Lyngfelt, A.; Leckner, B. Chem. Eng. Sci. 1989, 44 (2), 207-213.

(7) Lyngfelt, A.; Leckner, B. Chem. Eng. Sci. 1999, 54, 5573-5584.

(8) Dam-Johansen, K.; Hansen, P. F. B.; Østergaard, K. Chem. Eng. Sci. 1991, $46(3), 847-853$.

(9) Hansen, P. F. B.; Dam-Johansen, K.; Bank, L. H.; Østergaard, K. Proc. Int. Conf. Fluid. Bed Combust. 1991, 1, 73-82.

(10) Hansen, P. F. B; Dam-Johansen, K.; Østergaard, K. Chem. Eng. Sci. 1993, 48 (7), 1325-1341.

(11) Tarelho, L. A. C.; Matos, M. A. A.; Pereira, F. J. M. A. Fuel Process. Technol. 2005, 86, 1385-1401.

(12) Barin, I. Thermochemical Data of Pure Substances, 3rd ed.; VCH: Weinheim, Germany, 1995; ISBN 3-527-28745-0. 